\title{
Different scales determine the occurrence of aquatic macrophyte species in a tropical stream
}

\section{Gisele Biem Mori' ${ }^{1}{ }^{*} \odot$, Maria Teresa Fernandez Piedade ${ }^{2} \odot$, Aline Lopes $^{2,4} \odot$, Silvio Frosini de Barros Ferraz ${ }^{3} \odot$, Leonardo Farage Cancian ${ }^{1} \odot$ and Antonio Fernando Monteiro Camargo ${ }^{1} \oplus$}

Received: August 31, 2020

Accepted: January 11, 2021

\begin{abstract}
Distributions of aquatic macrophyte species are commonly associated with water chemistry characteristics. However, other environmental factors that can lead to the occurrence of aquatic plants in lotic ecosystems, such as dynamic habitats linked to the surrounding landscape, have been underestimated. This study aims to evaluate landscape features that may influence the occurrence of species of euhydrophyte aquatic macrophytes in a tropical river basin. We assessed the occurrence of the following seven species: Egeria densa, Cabomba furcata, Potamogeton pusillus, Potamogeton polygonus, Utricularia foliosa, Pistia stratiotes and Salvinia molesta. We also measured environmental variables related to three spatial scales, local (limnological), channel and riparian landscape, along $25.5 \mathrm{Km}$ of the Itanhaém River basin (São Paulo, Brazil). We found that local (limnological) and channel characteristics were important variables in determining the occurrence of aquatic macrophyte species while the landscape scale had little influence on species composition. Channel depth and margin slope were especially relevant abiotic variables in explaining the occurrence of four of the species but not P. pusillus, P. polygonus and U. foliosa. Our results highlight the importance of channel morphology for understanding aquatic plant occurrence and community composition in tropical rivers.
\end{abstract}

Keywords: aquatic plants, environmental gradients, landscape, lotic ecosystems, riparian vegetation

\section{Introduction}

Aquatic macrophytes occur in different types of aquatic ecosystem, but their distributions in lentic and lotic environments differ because of the distinct dynamics between these two habitats (Szoszkiewicz et al. 2014). They are usually more abundant in lakes when compared to rivers, because of their higher water light incidence and low water flow (Bornette \& Puijalon 2011). Their occurrence and distribution are mainly related to water characteristics, for instance, water transparency, temperature, $\mathrm{pH}$ values, electrical conductivity, and water and sediment nutrient concentrations (Alahuhta et al. 2012; Lopes et al. 2016; Moura-Júnior et al. 2019).

Lotic ecosystems are dynamic habitats because they are connected flowing water systems and are influenced by the upland areas (Vannote et al. 1980). Channel morphometry, for instance, channel width and depth, and hydrological characteristics, like water current velocity, are important environmental factors in rivers that differentiate them from lakes (Janauer et al. 2010; Gurnell et al. 2012; Steffen et al. 2014; Schneider et al.

1 Laboratório de Ecologia Aquática, Departamento de Ecologia, Instituto de Biociências, Universidade Estadual Paulista “Júlio de Mesquita Filho", 13506-900, Rio Claro, SP, Brazil

2 Grupo Ecologia, Monitoramento e Uso Sustentável de Áreas Úmidas, Instituto Nacional de Pesquisas da Amazônia, 69011-970, Manaus, AM, Brazil

3 Laboratório de Hidrologia Florestal, Departamento de Ciências Florestais, Escola Superior de Agricultura Luiz de Queiroz, 13418-900,

Piracicaba, SP, Brazil

4 Instituto de Ciências Biológicas, Coordenação de Ecologia, Universidade de Brasilia, 70910-900, Brasilia, DF, Brazil

* Corresponding author: giselebiem@gmail.com 
2015). In large floodplain tropical rivers, besides nutrient concentrations, the water dynamics due to the flood pulse (Junk \& Piedade 1993; Neiff et al. 2014), water connectivity (Thomaz et al. 2009; Sousa et al. 2011; Bleich et al. 2014) and climatic factors (Lopes et al. 2017; Nascimento et al. 2020) drive aquatic macrophytes' composition and distribution.

Streams run across different landscapes being influenced by the surrounding land cover. Riparian forests protect streams against eutrophication and sedimentation by keeping channel structure stability and reducing light incidence, nutrient and sediment input into the water (Niles et al. 1998; Dosskey et al. 2010). Different vegetation characteristics, such as size and canopy openness for instance, can influence aquatic plants' composition (Mackay et al. 2010; Kroflič et al. 2018). These forests are also an important allochthonous source of organic matter, especially in shaded areas, where autochthonous primary production can be limited due to light reduction (Fletcher et al. 2000). Land use changes caused by human activities, as in urban areas and farms, can act as sources of pollution to the streams and impact aquatic biodiversity (Tockner \& Stanford 2002). Different types of vegetation and changes in land use can, therefore, directly affect the aquatic ecosystems by altering the amount of nutrients, sediments and light that reaches the water bodies. Even in natural areas, the surrounding landscape can change along the river course, resulting in different habitats for biological communities and influencing downstream areas (Vannote et al. 1980).

Aquatic macrophytes are key components of aquatic ecosystems and are used worldwide as biological indicators of water quality and ecosystem integrity (Mackay et al. 2010; Beck et al. 2010; Radomski \& Perleberg 2012). Despite the importance of aquatic macrophytes, the mechanisms that control their occurrence and distribution in the tropics are poorly understood and little explored (Junk et al. 2014), and studies on this topic consider only limnological variables and were conducted mainly in lentic habitats. We investigated the influence of different scales of environmental variables on the occurrence of seven species of aquatic macrophytes in tropical streams that do not undergo regular flooding, by comparing the relative importance of each scale separately and their combined contribution. We hypothesized that, besides water characteristics, aquatic macrophytes are also controlled by channel and landscape variables, because channel morphology, riparian vegetation and current velocity influence the capacity of bank formation by plants, while landscape influences the amount of light, nutrients, organic matter and sediments in the water. Limnological, channel and landscape variables together explain the macrophyte distribution better than each of these scales individually.

\section{Materials and methods}

\section{Study area}

The Itanhaém River basin is located on the southern coast of São Paulo State, Brazil (between $23^{\circ} 50^{\prime}$ and $24^{\circ} 15^{\prime}$ S; $46^{\circ} 35^{\prime}$ and $47^{\circ} 00^{\prime} \mathrm{W}$; Fig. 1) and has an area of approximately $950 \mathrm{Km}^{2}$. The climate is tropical humid without dry season (Köppen). The mean temperature is $22.7^{\circ} \mathrm{C}$ and average annual rainfall is $2175 \mathrm{~mm}$ (Camargo et al. 2000). The river basin has three well-defined relief strata (plateau, escarpment and coastal plain): the plateau, with 700 to $900 \mathrm{~m}$ height, occupies approximately $28 \%$ of the total area; the escarpment, with 20-700 m height occupies $26 \%$ and the coastal plain, with $0-20 \mathrm{~m}$ height, occupies $49 \%$ of the area. The plateau and escarpment are covered by the Atlantic Forest and are inside the 'Serra do Mar State Park', the coastal plain is covered by Coastal Plain Forest (restinga), banana cultivation, small farms and mangroves, and the areas close to the river mouth are urban area of the Itanhaém city (Camargo \& Cancian 2016)

\section{Sampling design}

Our research area is $25.5 \mathrm{Km}$ long ranging from the headwaters to the river mouth, including the coastal plain and the beginning of the escarpment relief strata. We defined the location of the research area using a Landsat 5 TN image with $30 \mathrm{~m}$ resolution from 2011 (United States Geological Survey/USGS) with ArcGIS 9.3 (ESRI 2018) and established sampling points distant $500 \mathrm{~m}$ apart, totalizing 51 points. The first sampling point was near the river mouth and the last in the escarpment, defined by the end of aquatic plant species occurrence. Sampling was conducted in two weeks in July of 2012, during the period of lower rainfall and at low tide to facilitate the visualization of submerged species and to standardize the tide influence. We covered the area with a boat and used a GPS (Garmin Etrex) to reach the previously defined point.

\section{Environmental variables}

We measured the abiotic variables on three scales: (1) local scales, including water chemical and physical variables; (2) channel scales, including channel characteristics and sediment phosphorus and nitrogen contents; and (3) landscape scales, including terrain elevation and land use categories (Tab. 1). Water and sediment samples were collected and stored for determination of nutrients at the laboratory (Laboratório de Ecologia Aquática LEA - UNESP Rio Claro) following standardized protocols (Allen et al. 1974; Koroleff 1976; Golterman et al. 1978; Mackereth et al. 1978; Carmouze 1994). Conductivity, pH, turbidity, salinity, water temperature, channel depth and current velocity were measured in situ at the center of the channel. Underwater radiation was recorded at the center of the channel at 0 


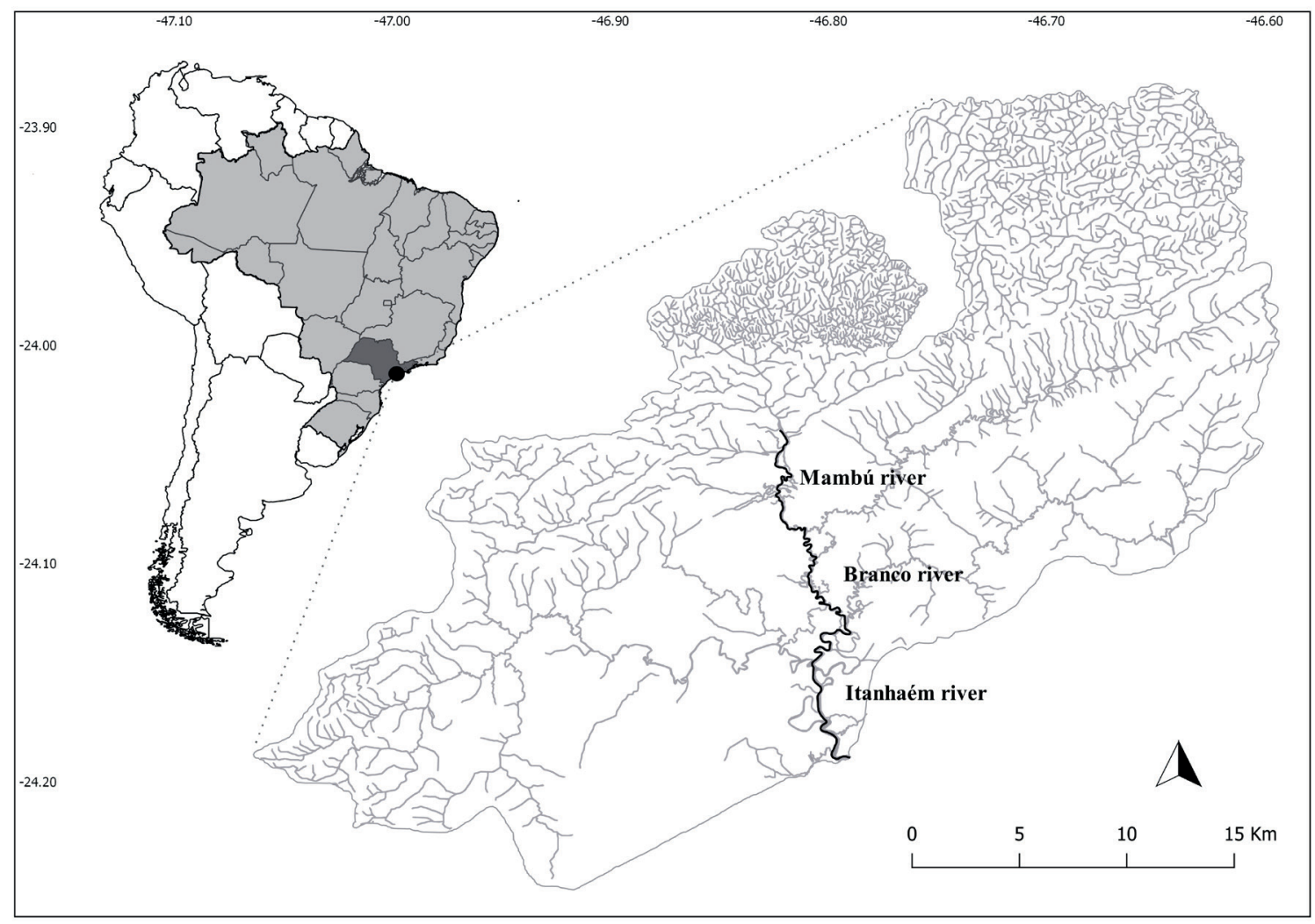

Figure 1. Location of the study area in the Itanhaém River basin, southern coast of São Paulo State (Brazil), highlighting the sampling area of $25.5 \mathrm{Km}$ (bold): (1) Itanhaém River, (2) Branco River and (3) Mambú River.

Table 1. Overview of the abiotic variables measured in the study, with the scale considered, variable name, unit and method and/ or equipment used.

\begin{tabular}{|c|c|c|}
\hline & Variables & Method/Equipment \\
\hline \multirow{14}{*}{ Local } & Temperature $\left({ }^{\circ} \mathrm{C}\right)$ & Horiba U10 \\
\hline & Hidrogenionic potential, $\mathrm{pH}$ & Horiba U10 \\
\hline & Salinity & Horiba U10 \\
\hline & Turbidity (NTU) & Horiba U10 \\
\hline & Electrical conductivity $\left(\mu \mathrm{S} . \mathrm{cm}^{-1}\right)$ & Horiba U10 \\
\hline & Dissolved oxygen (mg. $\left.\mathrm{L}^{-1}\right)$ & Oximeter WTW Oxi 315i \\
\hline & Underwater radiation & Underwater radiometer LI-COR LI-250 \\
\hline & Total Nitrogen $\left(\mu \mathrm{g} \cdot \mathrm{L}^{-1}\right)$ & Mackereth et al. 1978 \\
\hline & N-nitrite $\left(\mu \mathrm{g} \cdot \mathrm{L}^{-1}\right)$ & Mackereth et al. 1978 \\
\hline & N-nitrate $\left(\mu g \cdot L^{-1}\right)$ & Mackereth et al. 1978 \\
\hline & $\mathrm{N}$-amoniacal $\left(\mu \mathrm{g} \cdot \mathrm{L}^{-1}\right)$ & Koroleff 1976 \\
\hline & Total phosphorus $\left(\mu \mathrm{g} \cdot \mathrm{L}^{-1}\right)$ & Golterman et al. 1978 \\
\hline & Total alkalinity (mg. $\left.\mathrm{L}^{-1}\right)$ & Golterman et al. 1978 \\
\hline & Suspended sediment $\left(\mathrm{mg} . \mathrm{L}^{-1}\right)$ & Carmouze 1994 \\
\hline \multirow{8}{*}{ Channel } & Channel width (m) & $\begin{array}{l}\text { Measuring tape Western and Binocular distance } \\
\text { measure Bushnell ( }>17 \text { meters) }\end{array}$ \\
\hline & Channel depth (m) & Metered rope \\
\hline & Current velocity $\left(\mathrm{m} \cdot \mathrm{s}^{-1}\right)$ & Global Water Flow Probe \\
\hline & Sediment total Nitrogen (\%) & Allen et al. 1974 \\
\hline & Sediment total phosphorus, SP (\%) & Allen et al. 1974 \\
\hline & Canopy openness (\%) & Clinometer Suunto Tandem \\
\hline & Margin slope $\left({ }^{\circ}\right)$ & Clinometer Suunto Tandem \\
\hline & Vegetation cover (\%) & Sferic densiometer Widco \\
\hline Landscape & $\begin{array}{l}\text { Land use (\%): farm, anthropic, early succession, } \\
\text { mangrove, atlantic forest and coastal plain forest (restinga).. }\end{array}$ & ArcGis 9.3 (ESRI 2018) \\
\hline
\end{tabular}


and $0.2 \mathrm{~m}$ depths and subsequently the light attenuation coefficient $(\mathrm{k})$ was calculated $\left(\mathrm{k}=\left(\ln \mathrm{l}_{0}-\ln \mathrm{i}\right) / \mathrm{z}\right.$, where $l_{0}$ corresponds to light at surface, $i$ corresponds to light at 0.2 $\mathrm{m}$ depth, and $z$ is the depth). Channel width was measured using a measuring tape and with a binocular when width was higher than 17 meters. Canopy opening, margin slope and vegetation cover were measured in both margins. All measurements were obtained as triplicates and subsequently we calculated the average values. Terrain elevation was obtained for each sample point and the percentage of land use categories was calculated for a $250 \mathrm{~m}$ buffer around each point.

\section{Species occurrence}

In order to verify the extent of the influence of riparian characteristics on the occurrence of aquatic plants, we chose seven euhydrophyte species that largely occur in the area (Nunes et al. 2019) and excluded the amphibian and emerging species because they also depend on soil nutrients (Murphy et al. 2003; Santos \& Thomaz 2007; Meyer \& Franceschinelli 2011; Demars et al. 2014; Kutschker et al. 2014). We selected species belonging to three different life forms (Schulthorpe 1967): (1) rooted-submerged: Egeria densa Planch. (Hydrocharitaceae), Cabomba furcata Schult \& Schult. f. (Cabombaceae), Potamogeton pusillus L. subsp. pusillus and Potamogeton polygonus Cham. \& Schltdl. (Potamogetonaceae); (2) free-submerged: Utricularia foliosa L. (Lentibulariaceae) and (3) free-floating: Pistia stratiotes L. (Araceae) and Salvinia molesta D. Mitch (Salviniaceae). We recorded species' presence (1) or absence (0) per point on both margins, covering a distance of $10 \mathrm{~m}$ from the margin. When it was not possible to see the channel bottom, we used a hook to verify the occurrence of submerged species.

\section{Data analysis}

To describe how abiotic characteristics and species occurrence vary along the sampling area we used graphs of species ordination in relation to environmental gradients. We tested correlation between environmental variables using Pearson's correlation analysis with a threshold of $r=0.7$. The variables included were temperature, turbidity, water total nitrogen and phosphorus, nitrate, channel width and depth, current velocity, sediment nitrogen and phosphorus, canopy openness, vegetation cover, margin slope, terrain elevation and land use categories. To evaluate how environmental variables affect species occurrence we used generalized linear models (GLM) because they produce predictive models and are appropriate for presence and absence data (Gotelli \& McCabe 2002; Alahuhta et al. 2011), non-normal distribution assumption and different types of statistical errors (Gotelli \& McCabe 2002; Alahuhta et al. 2011). We built a model for each species and a series of stepwise multiple regressions for each abiotic variable and included only the significant ones in the multiple models.
In addition, we corrected $\mathrm{p}$-values for multiple comparisons using $\mathrm{p}$ adjustment of Holm (Holm 1979).

To evaluate the contribution of different scales of environmental variables (local, channel and landscape) on all species occurrence we used variation partitioning (Alahuhta et al. 2011; Borcard et al. 2011). We used variables' variance inflation factor (VIF) to test for collinearity. The data sets were divided into three environmental data matrices, where only variables with a VIF $<10$ were included: local (temperature, turbidity, electrical conductivity, total nitrogen, nitrate and total phosphorus); channel (width, depth, margin slope, current velocity, sediment nitrogen and phosphorus, canopy openness and vegetation cover); and landscape (farm, anthropic activity and Atlantic forest) and a biological data matrix (species occurrence). All analyses were carried out using the R platform ( $R$ Development Core Team 2020) considering significance of $5 \%$.

\section{Results}

Macrophytes were more frequent at intermediate portions of the study area and absent in the areas close to the river mouth (Fig. S1 in supplementary material). The most frequent species were $E$. densa (33 points, $64.7 \%$ of sampling areas) and Cabomba furcata (20 points, $39.2 \%$ ), followed by S. molesta (10 points, $19.6 \%$ ) and P. stratiotes (9 points, $17.6 \%)$. The least frequent species were Potamogeton pusillus (5 points, $9.8 \%$ ), P. polygonus and $U$. foliosa ( 2 points, $3.9 \%)$.

The water chemical and physical characteristics on a local scale influenced the occurrence of only two species, C. furcata and P. pusillus (Tab. 2). Higher water nitrate concentration was related to $C$. furcata (Fig. 2A) and low water alkalinity was related to P. pusillus (Fig. 2B).

Environmental variables of channel scale, especially channel depth and margin slope, influenced the occurrence of most species except P. polygonus, $P$. pusillus and U. foliosa (Tab. 2). Deeper portion of the channel (average of $6.9 \mathrm{~m}$ ), steeper margins and lower sediment nitrogen concentration were related to $C$. furcata and deeper channel was related to Egeria densa (average of $6.4 \mathrm{~m}$ ), Pistia stratiotes and Salvinia molesta (average of $~ 9.0$ m; Tab. 2 and Fig. 3). When considering the adjusted p-value, channel depth was related to $C$. furcata, E. densa and $S$. molesta and margin slope was related to $E$. densa.

The land cover was predominantly of restinga vegetation, followed by early succession vegetation and mangrove, which are concentrated at the river mouth, the most anthropized portion of the basin. Atlantic forest covers only $3 \%$ and farm covers $8 \%$, which are concentrated at the headwaters (Tab. S3 and Fig. S4 in supplementary material). This scale had less influence on species' occurrence compared to the previous ones, and only lower terrain elevation was related to $P$. stratiotes and S. molesta (Fig. 4), that is, flatter areas 
favor free-floating species. When considering the adjusted $\mathrm{p}$-value, this scale had no influence on any species.

The combination of local and channel scales explained most of species' occurrence ( $15 \%)$, followed by channel scale individually (11\%). Local scale individually explained $7 \%$ and landscape scale individually explained $0.1 \%$. The combination of all environmental scales explained $3 \%$ of species' occurrence.

\section{Discussion}

As we expected, besides water characteristics, the landscape and channel environmental variables were related to the occurrence of macrophyte species, mainly channel depth and margin slope. This is in line with the fact that landscape and channel characteristics are primary environmental factors influencing aquatic macrophyte species, due to the close relationship between streams, the surrounding landscape, and upstream areas. In fact, the occurrence of most species was related to channel depth, margin slope and terrain elevation.

Deeper channels with steep margins were related to E. densa and C. furcata, probably because this life-form has higher capacity to colonize deeper areas compared to other life-forms (Gantes \& Caro 2001; Bando et al. 2015). Lower sediment nitrogen concentration was related to $C$. furcata, a rooted-submerged species which is regulated by multiple factors but is usually linked to high water quality and preserved habitats (Søndergaard et al. 2010). These organisms can absorb nutrients via their leaves and roots but are more associated with nutrient availability in water (Lombardo \& Dennis-Cooke 2003; Bornette \& Puijalon 2011). Flatter areas were related to the free-floating species $P$. stratiotes and $S$. molesta, probably because the slow river flow favors non-rooted species. Interestingly, both species occurred in deeper parts of the channel. Depth is not a limiting factor linked to the free-floating life-form but seems

A

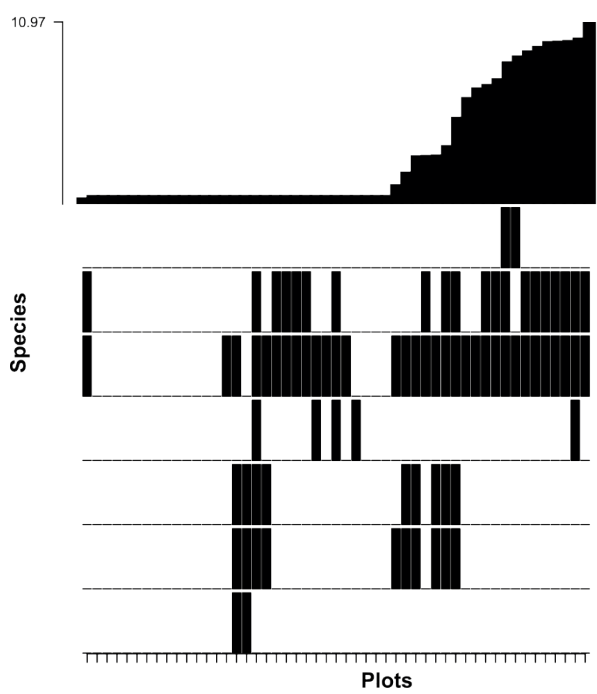
N-Nitrate $(\mu \mathrm{g} / \mathrm{L})$

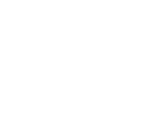
P. polygonus
C. furcata
E. densa
P. pusillus
P. stratiotes
S. molesta
U. foliosa

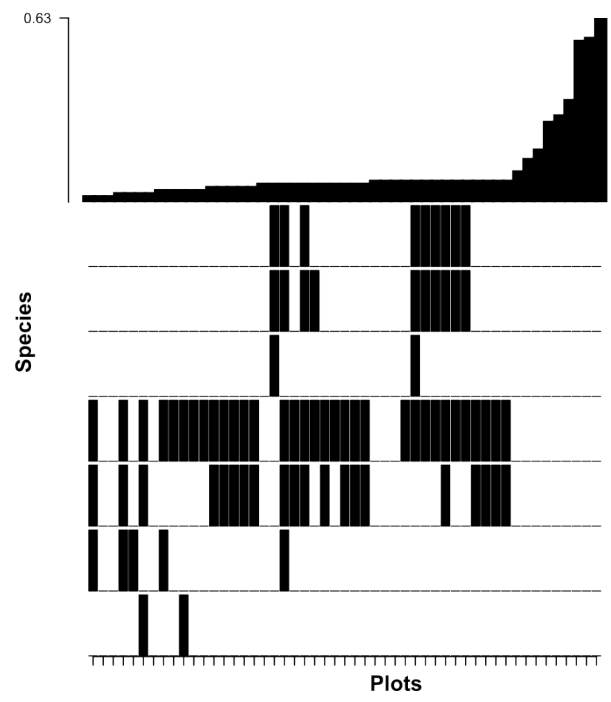

Alkalinity (mg/L)

P. stratiotes

S. molesta

U. foliosa

E. densa

C. furcata

P. pusillus

P. polygonus

Figure 2. Correlation of aquatic macrophyte species (P. stratiotes, S. molesta, E. densa, C. furcata, U. foliosa, P. pusillus, P. polygonus) in relation to environmental variables of local scale: $\mathbf{A}) \mathrm{N}$-nitrate $(\mu \mathrm{g} / \mathrm{L})$ and B) total alkalinity $(\mathrm{mg} / \mathrm{L})$ at 51 points along the $25.5 \mathrm{Km}$. Black bars indicate plots with species presence.

Table 2. Generalized linear models (GLM) of aquatic macrophyte species in relation to environmental variables. The columns indicate species name, the regression beta coefficient, significance (p-value) and p-adjusted by Holms' correction.

\begin{tabular}{|c|c|c|c|c|}
\hline \multirow{2}{*}{ Species } & Variables & B-coefficient & Adjusted p-value \\
\hline & Channel depth & 1.19 & 0.007 & $\mathbf{0 . 0 4 9}$ \\
\hline \multirow{2}{*}{ Cabomba furcata } & Margin slope & 0.24 & 0.01 & 0.07 \\
& Nitrate & 0.92 & 0.01 & 0.07 \\
\cline { 2 - 5 } & Substrate nitrogen & -73.5 & 0.01 & 0.07 \\
\hline \multirow{2}{*}{ Egeria densa } & Channel depth & 0.47 & 0.008 & $\mathbf{0 . 0 5 6}$ \\
\hline Potamogeton pusillus & Margin slope & 0.19 & 0.007 & $\mathbf{0 . 0 4 9}$ \\
\hline \multirow{2}{*}{ Salvinia molesta } & Total alkalinity & -77.41 & 0.02 & 0.14 \\
\hline \multirow{2}{*}{ Pistia stratiotes } & Channel depth & 0.87 & 0.004 & $\mathbf{0 . 0 2 8}$ \\
& Terrain elevation & -0.62 & 0.01 & 0.07 \\
& Channel depth & 1.14 & 0.01 & 0.07 \\
\end{tabular}


to be an important physical variable for aquatic plants, because it is related to other factors, such as turbidity and water transparency (Hrivnák et al. 2010).
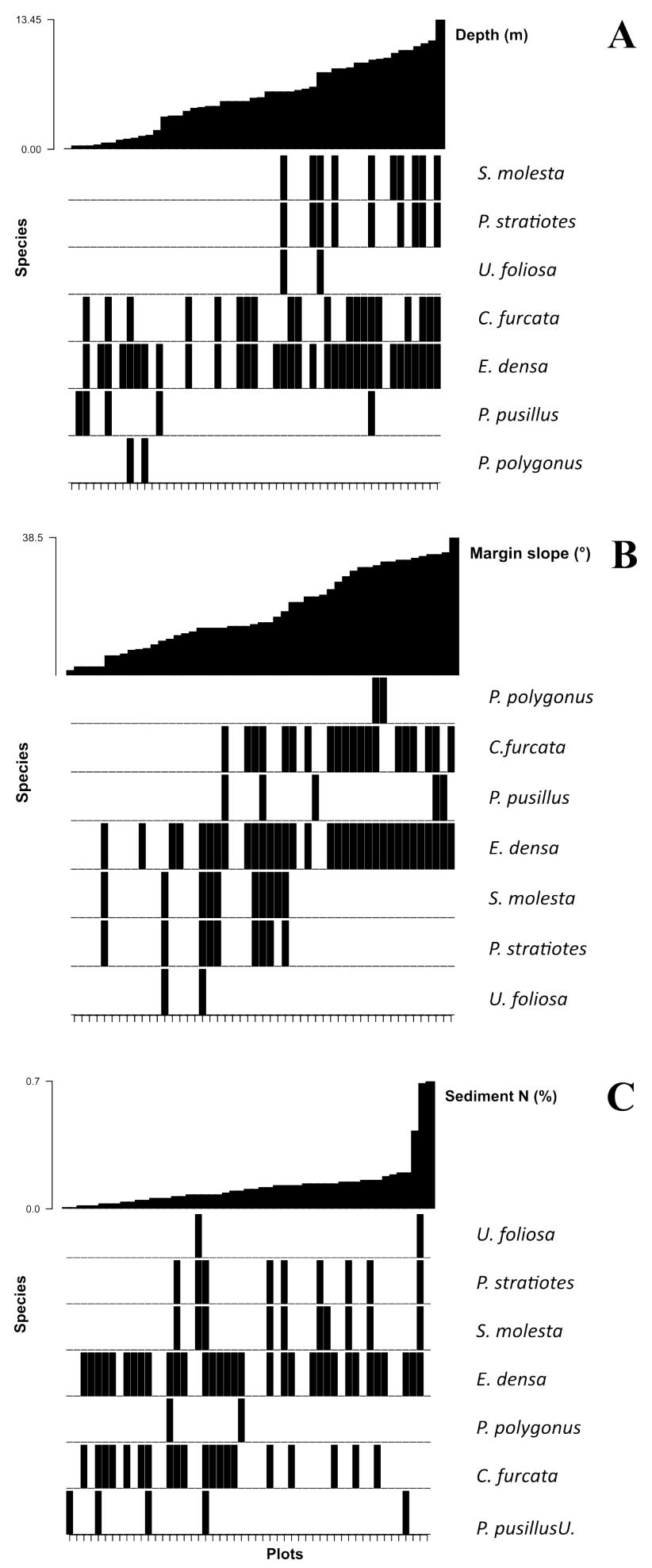

Figure 3. Correlation of aquatic macrophyte species (P. stratiotes, S. molesta, E. densa, C. furcata, U. foliosa, P. pusillus, P. polygonus) in relation to environmental variables of channel scale: $\mathbf{A}$ ) channel depth (m), B) margin slope $\left(^{\circ}\right.$ ) and $\mathbf{C}$ ) nitrogen of sediment (\%) at 51 points along the $25.5 \mathrm{Km}$. Black bars indicate plots with species presence.

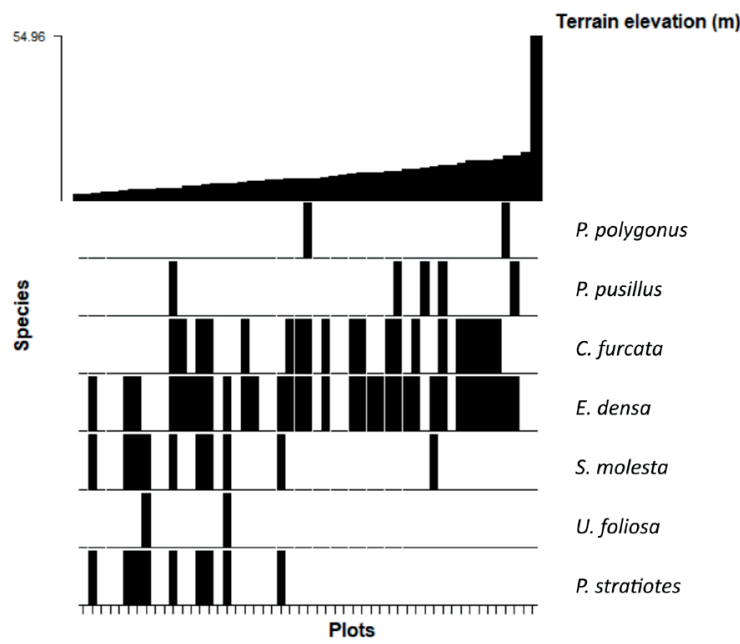

Figure 4. Correlation of aquatic macrophyte species (P. stratiotes, S. molesta, E. densa, C. furcata, U. foliosa, P. pusillus, P. polygonus) in relation to the environmental variable of landscape scale terrain elevation (m) at 51 points along $25.5 \mathrm{Km}$. Black bars indicate plots with species presence.

We expected that higher current velocity would favor $P$. pusillus and P. polygonus occurrence, since submerged species are assumed to be more resistant to physical damage caused by stronger water flows, and because higher flows may positively influence the gas exchange and sediment characteristics of this group of species (Chambers et al. 1991; Madsen et al. 2001); however, this was not verified. In fact, Potamogeton pusillus can thrive in lakes where there is no water flow (Lombardo et al. 2013), which can indicate that this species is not dependent on high current velocity and is not excluded in more lentic habitats. Besides that, we must consider that we sampled only during the lowrainfall season and we did not capture extreme rain events that certainly have occurred. Because these events can particularly affect current velocity and influence macrophyte distribution, further information about water current velocity is necessary to better understand its influence on species' distribution.

Followed by channel characteristics, water chemistry influenced species occurrence. Higher water nitrate concentration was related to $C$. furcata, which is an environmental driver of macrophyte composition (Kennedy et al. 2015). Water is probably the main source of nitrogen to this species, which explains the association with low nitrogen in the sediment we found. Lower alkalinity was related to the occurrence of P. pusillus, which is an important variable related to the genus Potamogeton (Hellquist 1980), but our results differed from those reported by (Riis et al. 2000), who found higher alkalinity associated with this genus, and can be a result of adaption of different species belonging to this genus to other environments. We expected that higher water nutrient availability would be especially related to free-floating species (Henry-Silva et al. 2008), but we did not find this relationship. In fact, higher growth 
rates of $S$. molesta at reduced water nutrient concentration was described for this river basin (Rubim \& Camargo 2001), and this result can indicate that channel variables have higher importance in lotic ecosystems rather than water variables (Schneider et al. 2018).

Surprisingly, land use categories were not related to species' occurrence. Some macrophytes are influenced by the increase of light, water nutrients and pollution caused by land cover change, like agriculture and urban areas (Alahuhta et al. 2011; Alahuhta et al. 2012). Our sampling area is mainly covered by Coastal Plain Forest, early succession vegetation and mangroves, with a small percentage of farm and anthropogenic uses. Probably, different types of natural vegetation do not restrict species' occurrence because they do not act as a source of pollution, increasing the amount of sediments and nutrients in the water bodies, and channel characteristics, for instance channel depth, influence more the underwater radiation, being more relevant for plant distribution along the river.

Local and channel variables combined were the environmental characteristics most related to macrophyte occurrence. Water chemical and physical characteristics are particularly important to vegetation establishment and growth because they are sources of nutrient supply and can be very limiting to species (Barendregt \& Bio 2003; Bornette \& Puijalon 2011). The free-floating species, for instance, usually grow under high water nutrient concentrations and can be related to disturbed areas, while submerged species can grow under a wide of water nutrient concentrations (Mjelde \& Faafeng 1997; Lombardo 2005). Channel variables individually were also very important for species' occurrence, which highlights the importance of channel morphology for macrophyte establishment and growth. Channel morphology is related to changes in light incidence in the water column and influences water current velocity; a higher water flow increases nutrient processing and oxygen concentration in rivers, favoring plant growth (Bleich et al. 2014; Bleich et al. 2015). Channel morphology, therefore, seems to be important for the occurrence of five of these species. The variance of species' occurrence that was not explained by environmental categories can be related to biotic interactions, but further studies are necessary to investigate these relationships. We found a substitution of species along the gradient with some overlap of $E$. densa and $C$. furcata with the free-floating species (Fig. 2), probably because these species are related to multiple factors, such as streamflow, nutrient availability, and substratum. The differences in river channel combined with biotic interactions can lead to a substitution of aquatic plant species and/or patches of species distributions along the river course (Khedr \& El-Demerdash 1997; Naiman \& Decamps 1997; Neiff et al. 2014).

To our knowledge this study is the first comparing the contribution of different scales of environmental variables, highlighting the importance of considering fine and landscape scales to better understand aquatic plant occurrence in tropical streams, which has been demonstrated only for lakes so far (Duarte \& Kalff 1990; June-Wells \&. 2016). Our results show that water chemistry and channel characteristics are important factors shaping macrophyte species occurrence in tropical lowland streams, but landscape has no influence on species composition. Channel depth and margin slope were especially important, highlighting the influence of channel characteristics to better understand and predict aquatic plant occurrence and distribution in lotic ecosystems.

\section{Acknowledgements}

We are grateful to Carlos Fernando Sanches and all colleagues for their help during field work. This project was supported by Fundação de Amparo à Pesquisa do Estado de São Paulo (FAPESP-2012/08510-5).

\section{References}

Alahuhta J, Kanninen A, Vuori KM. 2012. Response of macrophyte communities and status metrics to natural gradients and land use in boreal lakes. Aquatic Botany 103: 106-114.

Alahuhta J, Vuori KM, Luoto M. 2011. Land use, geomorphology and climate as environmental determinants of emergent aquatic macrophytes in boreal catchments. Boreal Environment Research 16: 185-202.

Allen SE, Grimshaw HM, Parkinson JA, Quarmby C. 1974. Chemical analysis of ecological materials. 1st. edn. Oxford, Blackwell Scientific Publication.

Bando FM, Michelan TS, Cunha ER, Figueiredo BRS, Thomaz SM. 2015. Macrophyte species richness and composition are correlated with canopy openness and water depth in tropical floodplain lakes. Brazilian Journal of Botany 38: 289-294.

Barendregt A, Bio AMF. 2003. Relevant variables to predict macrophyte communities in running waters. Ecological Modelling 160: 205-217.

Beck MW, Hatch LK, Vondracek B, Valley RD. 2010. Development of a macrophyte-based index of biotic integrity for Minnesota lakes. Ecological Indicators 10: 968-979.

Bleich ME, Mortati AF, André T, Teresa M, Piedade F. 2014. Riparian deforestation affects the structural dynamics of headwater streams in Southern Brazilian Amazonia. Tropical Conservation Science 7: 657-676.

Bleich ME, Piedade MTF, Mortati AF, André T. 2015. Autochthonous primary production in southern Amazon headwater streams: Novel indicators of altered environmental integrity. Ecological Indicators 53: 154-161.

Borcard D, Gillet F, Legendre P. 2011. Numerical Ecology with R. 1st. edn. New York, Springer.

Bornette G, Puijalon S. 2011. Response of aquatic plants to abiotic factors: A review. Aquatic Sciences 73: 1-14.

Camargo AFM, Cancian LF. 2016. Ecologia da bacia do rio Itanhaém: características limnológica e uso do solo. In: Moraes MEB, Lorandi R. (eds.) Métodos e ténicas de pesquisa em bacias hidrográficas. Ilhéus, Editus.

Camargo AFM, Florentino ER. 2000. Population dynamics and net primary production of the aquatic macrophyte Nymphaea rudgeana C. F. Mey in a lotic environment of the Itanhaém river basin (SP, Brazil). Revista Brasileira de Biologia 60: 83-92.

Carmouze JP. 1994. O metabolismo dos ecossistemas aquáticos: fundamentos teóricos, métodos de estudo e análises químicas. São Paulo, Edgar Blücher Ltda/Fundação de Amparo à Pesquisa do Estado de São Paulo. 


\section{Gisele Biem Mori, Maria Teresa Fernandez Piedade, Aline Lopes, Silvio Frosini de Barros Ferraz, Leonardo Farage Cancian and Antonio Fernando Monteiro Camargo}

Chambers PA, Prepas EE, Hamilton HR, Bothwell ML. 1991. Current Velocity and Its Effect on Aquatic Macrophytes in Flowing Waters. Ecological Applications 1: 249-257.

Demars B, Wiegleb G, Harper D, Bröring U, Brux H, Herr W. 2014. Aquatic Plant Dynamics in Lowland River Networks: Connectivity, Management and Climate Change. Water 6: 868-911.

Santos AM, Thomaz SM. 2007. Aquatic macrophytes diversity in lagoons of a tropical floodplain: The role of connectivity and water level. Austral Ecology 32: 177-190.

Dosskey MG, Vidon P, Gurwick NP, Allan CJ, Duval TP, Lowrance R. 2010. The role of riparian vegetation in protecting and improving water quality in streams. Journal of The American Water Resources Association 46: 261-277.

Duarte CM, Kalff J. 1990. Patterns in the Submerged Macrophyte Biomass of Lakes and the Importance of the Scale of Analysis in the interpretation. Canadian Journal of Fisheries and Aquatic Sciences 47: 357-363.

ESRI - Environmental Systems Research Institute. 2018. https://www.esri. com/en-us/arcgis/about-arcgis/overview. 20 Jun. 2018.

Fletcher DE, Wilkins SD, McArthur J, Meffe GK. 2000. Influence of riparian alteration on canopy coverage and macrophyte abundance in Southeastern USA blackwater streams. Ecological Engineering 15: 67-78.

Gantes HP, Caro AS. 2001. Environmental heterogeneity and spatial distribution of macrophytes in plain streams. Aquatic Botany 70: 225-236

Golterman HL, Clyno RS, Ohnstad MAM. 1978. Methods for physical and chemical analysis of freshwater. 1st. edn. London, Blackwell Science Publication.

Gotelli NJ, McCabe DJ. 2002. Species co-occurrence: A meta-analysis of J. M. Diamond's assembly rules model. Ecology 83: 2091-2096.

Gurnell AM, Bertoldi W, Corenblit D. 2012. Changing river channels: The roles of hydrological processes, plants and pioneer fluvial landforms in humid temperate, mixed load, gravel bed rivers. Earth-Science Reviews 111: 129-141.

Hellquist CB. 1980. Correlation of Alkalinity and the Distribution of Potamogeton in New England. Rhodra 82: 331-344.

Henry-Silva GG, Camargo AFM, Pezzato MM. 2008. Growth of freefloating aquatic macrophytes in different concentrations of nutrients. Hydrobiologia 610: 153-160.

Holm S. 1979. A simple rejective test procedure. Scandinavian Journal of Statistics 6: 65-70.

Hrivnák R, Ot'ahel'ová H, Valachovič M, Pal'ove-Balang P, Kubinská A. 2010. Effect of environmental variables on the aquatic macrophyte composition pattern in streams: a case study from Slovakia. Fundamental and Applied Limnology, Archiv für Hydrobiologie 177: 115-124

Janauer GA, Schmidt-Mumm U, Schmidt B. 2010. Aquatic macrophytes and water current velocity in the Danube River. Ecological Engineering 36: 1138-1145.

June-Wells M, Gallagher F, Hart B, Malik V, Bugbee G. 2016. The relative influences of fine and landscape scale factors on the structure of lentic plant assemblages. Lake and Reservoir Management 32: 116-131.

Junk WJ, Piedade MTF. 1993. Herbaceous plants of the Amazon floodplain near Manaus: Species diversity and adaptations to the flood pulse. Amazoniana XII: 467-484

Junk WJ, Piedade MTF, Lourival R, et al.2014. Brazilian wetlands: Their definition, delineation, and classification for research, sustainable management, and protection. Aquatic Conservation: Marine and Freshwater Ecosystems 24: 5-22.

Kennedy MP, Lang P, Grimaldo JT, et al. 2015. Environmental drivers of aquatic macrophyte communities in southern tropical African rivers: Zambia as a case study. Aquatic Botany 124: 19-28.

Khedr AHA, El-Demerdash MA. 1997. Distribution of aquatic plants in relation to environmental factors in the Nile Delta. Aquatic Botany 56: 75-86.

Koroleff F. 1976. Determination of nutrients. In: Grasshoff E, Kremling E. (eds.) Methods of seawater analysis. New York, Verlag Chemie Weinhein. p. 117-181.
Kroflič A, Germ M, Golob A, Stibilj V. 2018. Does extensive agriculture influence the concentration of trace elements in the aquatic plant Veronica anagallis-aquatica? Ecotoxicology and Environmental Safety 150: 123-128.

Kutschker AM, Epele LB, Miserendino ML. 2014. Aquatic plant composition and environmental relationships in grazed Northwest Patagonian wetlands, Argentina. Ecological Engineering 64: 37-48.

Lombardo P. 2005. Applicability of littoral food-web biomanipulation for lake management purposes: Snails, macrophytes, and water transparency in northeast Ohio shallow lakes. Lake and Reservoir Management 21: 186-202.

Lombardo P, Dennis-Cooke G. 2003. Ceratophyllum demersum Phosphorus interactions in nutrient enriched aquaria. Hydrobiologia 497: 79-90.

Lombardo P, Mjelde M, Källqvist T, Brettum P. 2013. Seasonal and scale-dependent variability in nutrient- and allelopathy-mediated macrophyte-phytoplankton interactions. Knowledge and Management of Aquatic Ecosystems 409: 10. doi: 10.1051/kmae/2013055

Lopes A, Parolin P, Piedade MTF. 2016. Morphological and physiological traits of aquatic macrophytes respond to water chemistry in the Amazon Basin: an example of the genus Montrichardia crueg (Araceae). Hydrobiologia 766: 1-15.

Lopes A, Wittmann F, Schöngart J, Householder JE, Piedade MTF. 2017. Modeling of regional- and local-scale distribution of the genus Montrichardia crueg. (Araceae). Hydrobiologia 789: 45-57.

Mackay SJ, James CS, Arthington AH. 2010. Macrophytes as indicators of stream condition in the wet tropics region, Northern Queensland, Australia. Ecological Indicators 10: 330-340.

Mackereth FIF, Heron J, Talling JF. 1978. Water analysis: some revised methods for limnologist. 1st. edn. London, Freshwater Biological Association.

Madsen JD, Chambers PA, James WF, Koch EW, Westlake DF. 2001. The interaction between water movement, sediment dynamics and submersed macrophytes. Hydrobiologia 444: 71-84.

Meyer ST, Franceschinelli EV. 2011. Influência de variáveis limnológicas sobre a comunidade das macrófitas aquáticas em rios e lagoas da cadeia do Espinhaço, Minas Gerais, Brasil. Rodriguésia 62: 743-758.

Mjelde M, Faafeng BA. 1997. Ceratophyllum demersum hampers phytoplankton development in some small Norwegian lakes over a wide range of phosphorus concentrations and geographical latitude. Freshwater Biology 37: 355-365.

Moura-Júnior EG, Pott A, Severi W, Zickel CS. 2019. Response of aquatic macrophyte biomass to limnological changes under water level fluctuation in tropical reservoirs. Brazilian Journal of Biology 79: 120-126.

Murphy KJ, Dickinson G, Thomaz SM, et al. 2003. Aquatic plant communities and predictors of diversity in a sub-tropical river floodplain: The upper Rio Paraná, Brazil. Aquatic Botany 77: 257-276.

Naiman RJ, Decamps H. 1997 The ecology of interfaces: Riparian Zones. Annual Review of Ecology, Evolution, and Systematics 28: 621-658.

Nascimento FAO, Moura-Júnior EG, Freitas EDSN, Rodrigues RG. 2020. Modeling the potential distribution of Anamaria heterophylla (Giul. \& V.C. Souza) V.C. Souza (Plantaginaceae) in the Caatinga. Oecologia Australis 24: 76-87.

Neiff JJ, Casco SL, Mari EKA, Rienzo JA, Poi ASG. 2014. Do aquatic plant assemblages in the Paraná River change along the river's length? Aquatic Botany 114: 50-57.

Niles JM, Keyser P, Box PO, et al. 1998. Development, maintenance and role of riparian vegetation in the river landscape. Freshwater Biology 40: 497-516.

Nunes LSC, Umetsu CA, Rodrigues MEF, Pott VJ, Camargo AFM. 2019. Inventory of aquatic macrophyte species in coastal rivers of the São Paulo state, Brazil. Oecologia Australis 23: 829-845.

R Development Core Team. 2020. R: A language and environment for statistical computing. R Foundation for Statistical Computing, Vienna, Austria. www.R-project.org. 03 Marc. 2020.

Radomski P, Perleberg D. 2012. Application of a versatile aquatic macrophyte integrity index for Minnesota lakes. Ecological Indicators 20: $252-268$ 


\section{Different scales determine the occurrence of aquatic macrophyte species \\ in a tropical stream}

Riis T, Sand-Jensen K, Vestergaard O. 2000. Plant communities in lowland streams: species composition and environmental factors. Aquatic Botany 66: 255-272.

Rubim MAL, Camargo AFM. 2001. Taxa de crescimento específico da macrófita aquática Salvinia molesta Mitchell em um braço do Rio Preto, Itanhaém, São Paulo. Acta Limnologica Brasiliensia 13: 75-83.

Schneider B, Cunha ER, Marchese M, Thomaz SM. 2015. Explanatory variables associated with diversity and composition of aquatic macrophytes in a large subtropical river floodplain. Aquatic Botany 121: 67-75.

Schneider B, Cunha ER, Marchese M, Thomaz SM. 2018. Associations between Macrophyte Life Forms and Environmental and Morphometric Factors in a Large Sub-tropical Floodplain. Frontiers in Plant Science 9: 195. https://doi.org/10.3389/FPLS.2018.00195

Schulthorpe CD. 1967. The biology of aquatic plants. London, Edward Arnold., Søndergaard M, Johansson LS, Lauridsen TL, Jørgensen TB, Liboriussen L, Jeppesen E. 2010. Submerged macrophytes as indicators of the ecological quality of lakes. Freshwater Biology 55: 893-908.
Sousa WTZ, Thomaz SM, Murphy KJ. 2011. Drivers of aquatic macrophyte community structure in a Neotropical riverine lake. Acta Oecologica 37: 462-475.

Steffen K, Leuschner C, Müller U, Wiegleb G, Becker T. 2014. Relationships between macrophyte vegetation and physical and chemical conditions in northwest German running waters. Aquatic Botany 113: 46-55.

Szoszkiewicz K, Budka A, Kayzer D, Pietruczuk K. 2014. Diversity of macrophyte communities and their relationship to water quality in different types of lowland rivers in Poland. Hydrobiologia 737: 77-85.

Thomaz SM, Carvalho P, Padial AA, Kobayashi JT. 2009. Temporal and spatial patterns of aquatic macrophyte diversity in the Upper Paraná River floodplain. Revista Brasileira de Biologia 69: 617-625.

Tockner K, Stanford JA. 2002. Riverine flood plains: Present state and future trends. Environmental Conservation 29: 308-330.

Vannote RL, Minshall GW, Cummins KW, Sedell JR, Cushing CE. 1980. The river continuum concept. Canadian Journal of Fisheries and Aquatic Sciences 37: 130-137 